\title{
移植腎血管異常に対する血行再建の臨床的検討
}

\begin{tabular}{|c|c|c|c|c|c|c|}
\hline \multicolumn{7}{|c|}{ 北海道大学医学部泌尿器科学講座 } \\
\hline 三浦 & 正義 & 関 利盛 & 原田 & 浩 & 丹田 & 勝敏 \\
\hline 力石 & 辰也 & 野々村克也 & 小柳 & 知彦 & 富樫 & 正樹 \\
\hline
\end{tabular}

\section{CLINICAL EVALUATION OF DONOR RENAL ARTERY RECONSTRUCTION IN KIDNEY TRANSPLANTATION}

\author{
Masayoshi Miura, Toshimori Seki, Hiroshi Harada, Katsutoshi Tanda, \\ Tatsuya Chikaraishi, Katsuya Nonomura, Tomohiko Koyanagi \\ and Masaki Togashi \\ Department of Urology, Hokkaido University, School of Medicine
}

This retrospective study describes the experience of arterial reconstruction of donor kidney in our institute since 1982.

(Materials and Methods) Of total 56 living related kidney transplantations 15 required renal arterial reconstruction or ligation of donor kidneys. Renal arterial reconstruction was employed for 11 cases (end to side anastomosis [4 cases], conjoined anastomosis [3], hypogastric artery graft interposition [3], other [1]), while simple ligation was employed for 4 . Bench surgery with microsurgical techniques was employed for the repair. Elective surgery was done for preoperatively defined multiple renal arteries [10] and aneurysm [1], while imperative surgery for intraoperatively detected accessory arteries [2] and surgical injuries [2]. Postoperative patency of arteries and renal function (GFR) was evaluated by $99 \mathrm{mTc}$-DTPA renoscintigraphy.

(Results) The mean total ischemic time of reconstructed cases was $135 \mathrm{~min}$., while that of ligated ones was $67 \mathrm{~min}$. None of them required hemodialysis due to acute tubular necrosis. Postoperative graft arterial patency was impaired in 2 of 11 reconstructed cases (18\%), while it was impaired in 3 of 4 ligated cases (75\%). Two failure attempts of arterial reconstruction cases were all imperative ones. Postoperative GFR of the graft was well preserved in all cases.

(Conclusion) We conclude that (1) Ligation and imperative surgery tend to be associated with renal infarction, although it does not affect GFR. (2) Renal artery reconstruction was highly successful in preserving renal mass (or normal cortical image), albeit longer ischemic time than simple ligation. (3) Considering importance of preserved nephron mass in clinical renal transplantation every attempt should be made to repair the donor arterial anomalies when expected (elective) or found (imperative). (4) Thorough preoperative evaluation of donor renal arteries is mandatory.

Key words: renal transplantation, reconstruction, multiple arteries

要旨：(目的) ドナー腎動脈に対する血行再建の経験を retrospective に検討した。

（対象と方法）56例の血縁間生体腎移植の内，15例が腎動脈の再建または結禁を要した。腎動脈の血 行再建は11例に対し施行され (end-to-side 法が 4 例, conjoined 法が 3 例, hypogastric artery 法が 3 例, 他 1 例)，一方単なる結紮は 4 例に対し施行された. 待機手術は 10 例の複数腎動脈， 1 例の腎動脈瘤 に対して行われた一方，緊急の腎動脈再建は 2 例の術中発見の細い分枝に対し，また 2 例の術中損傷に 施行された。上記 15 例に対し, 総阻血時間, そしてDTPA 腎動態シンチにて腎実質欠損像の有無及び腎 機能 (GFR) を評価した。 
（結果）血行再建例の平均の総阻血時間は135分（中央値）であり，結紮例では67分であった.どの症 例も急性尿細管壊死のための血液透析を要しなかった。術後の腎実質欠損は再建例では11例中 2 例認め たのに対し結禁例では 4 例中 3 例で認めた。術後の GFR は全例良好であった。

(結論) 結紮と緊急の腎動脈再建は GFRには影響しないが腎梗塞と関連する傾向があった。血行再建 は結禁よりも総阻血時間が長いにも関わらず腎実質を温存できた。腎移植においてはネフロン温存を目 指し, ドナー腎動脈異常が判明した際には再建に尽力すべきである. ドナー腎動脈の詳細な術前評価は 必須である。

キーワード：腎移植, 血行再建, 複数腎動脈

\section{緒 言}

慢性腎不全に対する根治的治療法として腎移植は確 立された治療法となりその成績向上も著しい.しかし， 生体腎移植が主流である本邦においては, donor source の拡大は必須である。従来, donor 腎動脈に異 常を伴った症例の腎移植は敬遠される傾向にあった が，近年血管外科の技術の進歩に伴い，このような症 例に対しても積極的に腎移植が行われるようになりつ つある ${ }^{1) ~ 8)}$. 今回我々は donor 腎動脈異常に対する血 行再建術の実際, そしてその意義について retrospectiveに検討したので報告する.

\section{対象・方法}

1982年10月より1995年 1 月までの間の56例の生体腎 移植症例のうち, donor の腎動脈が複数存在したもの, 腎動脈瘤の存在したもの ${ }^{15)}$, 腎摘出術中に腎動脈損傷 があった15例の donor, recipientを対象とした。 Recipient は男性 9 例, 女性 6 例, 年齢は 19 歳から 38 歳, 透析歴は HD 14例 ( 5 カ月 12年), CAPD 1 例 ( 5 年)であった。免疫抑制法は, ciclosporin 導入以前 のもの 2 例, ciclosporin 導入以降のものが13例であっ た. donor は男性 5 例, 女性10例, 年齢は22歳〜 69歳で あった.これらの15症例を対象として以下の項目を検 討した。

（1）donor 腎動脈の処理方法，（2）血管再建を必要 とした理由,（3）総阻血時間,（4）99mTc-DTPA 腎動 態シンチグラフィーの（以下腎動態シンチ）における image 上の欠損像の有無（腎実質の RI 取り込みの欠 損像 (defect) が肉眼的に明らかに確認されたものを impaired とし, 確認されなかったものを intactとし た)，(5）術後早期の腎動態シンチにて算出される glomerular filtration rate (以下 GFR). 数值は median で示し, 統計学的有意差の検定には MannWhitney U-test を用いた。

\section{結 果}

（1）donor 腎動脈の処理方法
15例中，4 例は accessory artery を結紮し，11例は 血行再建術を施行した。結禁した動脈は上極または下 極を栄養する polar arteryであった（ $\phi 1.4 〜 3.5$ $\mathrm{mm})$. 我々が行った血行再建の術式を Figure に示し た. Conjoined 法 (A) は径がほぼ等しい 2 本の動脈を 側々吻合することで，1 本化して内腸骨動脈（以下 hypogastric artery, HGA） に端々吻合する方法で 3 例に施行された. End to side 法（B）は径の細い動脈 を太い動脈に端側吻合し, それを HGA に端々吻合す る方法で，4 例に施行された. HGA graft 法 (C) は HGA autologous graft を recipient より採取し，その 分枝を利用し血行再建を行い, それを移植腎と recipient 体内の HGA 断端との間に interposition する方法 で， 3 例に施行された. 以上の 3 法は腎摘出術後, simple cooling を施し, bench 上にて施行された. なお, 血行再建は7-0 Prolene の結節縫合で行い，2.0倍の拡 大鏡を用いた。また Parallel end to side 法 (D) の樣 に，2 本の腎動脈をそのまま外腸骨動脈に並列に端側 吻合する方法も 1 例に対し施行された。

（2）血行再建を必要とした理由

donor 腎動脈の再建・処理（結紮）を必要とした背景 は以下の如くである. 術前評価により donor 腎動脈異 常の存在が事前に明らかになっており, elective surgery が行われたのは11症例である.1例は腎動脈瘤を 合併しその切除を要した症例であったが他の 10 例は複 数腎動脈を有するものであった。また，予期せぬ事態 で imperative surgery が必要となった 4 症例は術前 評価が不十分で accessory arteryを術中発見したも のが 2 例，また腎摘出術中の不測の腎動脈損傷による ものが 2 例であった。

（3）総阻血時間

総阻血時間は, 血行再建を行った症例（11例）で 90〜221分 (median 125分), 結禁を行った症例 ( 4 例) で50〜83分（median 66.5分）と有意に（ $\mathrm{p}=0.0041 ）$ 血行再建例では延長していた。血行再建を行った症例 
Fig. 1 腎動脈再建術式

(A) Conjoined method ( 3 cases)

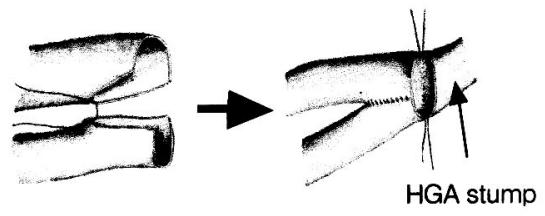

(C) HGA autologous graft method (3)

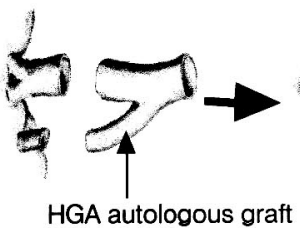

(B) End-to-side method (4 cases)

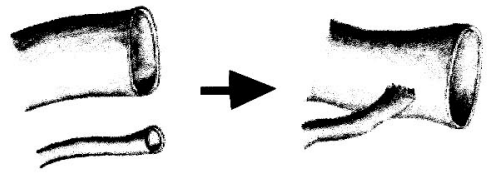

(D)Parallel end-to-side method (1)

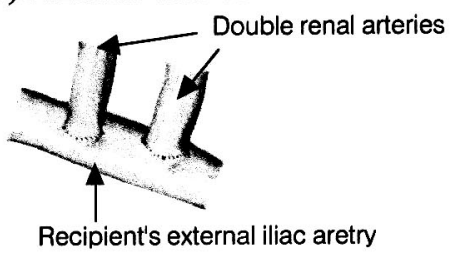

表 総阻血時間, 腎実質欠損の有無及び，系球体濾過率

\begin{tabular}{c|c|c|l|l|l|c|c|c|c}
\hline $\begin{array}{c}\text { Case } \\
\text { No. }\end{array}$ & Recipient & Donor & Operation & Diameter & Reason & TIT & Defect & GFR(P/O) & GFR(Max) \\
\hline 1 & $37 \mathrm{~F}$ & $69 \mathrm{~F}$ & HGA graft & 2.7 & imperative & 150 & yes $\dagger$ & $*$ & $*$ \\
2 & $25 \mathrm{~F}$ & $50 \mathrm{~F}$ & HGA graft & 3.0 & imperative & 221 & no & unknown & unknown \\
3 & $14 \mathrm{M}$ & $38 \mathrm{~F}$ & HGA graft & $2.5,5.1$ & elective & 152 & no & unknown & unknown \\
4 & $36 \mathrm{M}$ & $64 \mathrm{M}$ & conjoined & $6.0,4.5$ & elective & 125 & no & 31 & 65 \\
5 & $27 \mathrm{M}$ & $53 \mathrm{~F}$ & conjoined & $4.6,3.3$ & elective & 117 & no & 36 & 43 \\
6 & $24 \mathrm{M}$ & $66 \mathrm{~F}$ & conjoined & $5.0,3.0$ & elective & 122 & no & 43 & 62 \\
7 & $28 \mathrm{~F}$ & $57 \mathrm{~F}$ & end-to-side & $1.7,5.0$ & elective & 90 & no & 34 & 59 \\
8 & $25 \mathrm{~F}$ & $55 \mathrm{~F}$ & end-to-side & $1.8,5.4$ & elective & 115 & no & 50 & unknown \\
9 & $25 \mathrm{M}$ & $46 \mathrm{~F}$ & end-to-side & & elective & 140 & no & unknown \\
10 & $19 \mathrm{~F}$ & $47 \mathrm{~F}$ & end-to-side & 6.2 & elective & 100 & yes $\ddagger$ & 42 & 54 \\
11 & $32 \mathrm{M}$ & $22 \mathrm{~F}$ & parellel e-s & & elective & 151 & unknown & unknown & unknown \\
12 & $38 \mathrm{~F}$ & $66 \mathrm{~F}$ & ligated & 1.4 & elective & 83 & no & 50 & 55 \\
13 & $31 \mathrm{M}$ & $69 \mathrm{M}$ & ligated & $2.0,1.5$ & imperative & 63 & yes & 27 & 50 \\
14 & $27 \mathrm{M}$ & $32 \mathrm{~F}$ & ligated & 2.8 & imperative & 50 & yes & 57 \\
15 & $36 \mathrm{M}$ & $33 \mathrm{M}$ & ligated & 3.5 & elective & 70 & yes & unknown & unknown \\
\hline
\end{tabular}

TIT は総阻血時間を示す (単位は分)。GFR(P/O) は術翌日の GFR 值 $(\mathrm{ml} / \mathrm{min}$.). GFR (Max) は手術後 2 ないし 4 週の最高値 (ml/ min.). Diameter は再建した動脈徍 $(\mathrm{mm})$.

*MAG3シンチを施行したため比較が行えなかったもの.

†下極を栄養する動脈が術後13日に閉塞し腎梗塞を発症したもの.

‡下極を栄養する動脈が術後 7 日に閉塞し腎梗塞を発症したもの.

の中では, conjoined 法 ( 3 例) は117〜125分 (median 122分), end-to-side 法（4 例）は90〜140分 (median 107.5分), HGA graft 法は150～221分 (median 152分) と HGA graft 法 ( 3 例) が総阻血時間が最も長かった. 直接外腸骨動脈に並列に吻合した症例（1例）は151分 と比較的総阻血時間が長かった。全例血流再開後の利 尿が得られ，急性尿細管壊死を起こした症例はなかっ た.
（4）腎動態シンチにおける image 上の欠損像の有 無

腎動脈分枝を結紮した症例においては 4 例中 3 例 (75\%)に defect が認められ impaired であったのに対 し，血行再建術を行った症例では術後 1 週間以内では 11例全例が defect 認めず intactであった。しかし， 血行再建を行った11例中 2 例が，術後 7 日目及び13日 目で腎シンチ上 defect を認めるようになった。これら 
2 例に対しては下極を栄養する腎動脈分枝が閉塞, 腎 梗塞を生じたものと考えられ，血管造影で閉塞が確認 された。直ちに抗血栓療法が開始されたが再開通は得 られなかった。尚, 術中, 術後, ルーチンの抗凝固療 法は行わなかった. したがって, 血行再建を行った11 例中 2 例 (18\%) が impaired であった（1 例は end-toside 法，1例は HGA graft 法). 全体としては imperative な症例（結惄 2 例, 血行再建 2 例）は 4 例中 3 例 (75\%) が impaired であり, elective な症例(結禁 2 例, 血行再建 9 例）は11例中 1 例のみ（9\%）impaired で あった。

（5）術後早期の腎動態シンチにて算出される GFR 值

腎動態シンチにより算出される GFR は手術直後 （術翌日）及び後期（手術後 $2 \sim 4$ 週の最高値）の両者 を比較した。血行再建術を施行した群においては median GFR は術直後で $39 \mathrm{ml} / \mathrm{min}$ ，後期は $63.5 \mathrm{ml} /$ minであり, 結禁を行った群においては術直後で50 $\mathrm{ml} / \mathrm{min}$, 後期は $76 \mathrm{ml} / \mathrm{min}$ であった。両者とも術翌日 から良好な腎機能が得られた.GFR 值には統計学的差 を認めなかった(術直後 $\mathrm{p}=0.5169$, 後期 $\mathrm{p}=0.1948$ ).

\section{考 察}

腎移植の需要が増加するにつれ, 複数腎動脈や腎動 脈異常を伴った donor 腎に直面する機会も増えてき ている．近年の血管外科技術の進歩により，そのよう な donor 腎も腎移植に用いられるようになってき $た^{1) \sim 9)}$. 腎動脈は解剖学的に variation が多く, 複数腎 動脈の頻度は, 片側のみでは23〜 $25 \%$, 両側例は $10 \%$ 存在するといわれている ${ }^{177}$. 我々の施設においても摘 出腎が複数腎動脈であった頻度は, 生体腎のみで56例 中12例 $(21.4 \%)$, 死体腎移植も含めると58例中13例 (22.4\%) であった ${ }^{10)}$.

摘出腎の選択に際しては, 積極的な血行再建術によ り,血管の本数よりも, donor の腎機能をより優先して 考えられるようになった。我々は分腎機能比に左右差 のない場合は原則として腎動脈が 1 本の腎を選んでい る。しかし，分腎機能比に明らかな差がある場合は腎 動脈が複数あっても腎機能の低い方の腎を選択し，ま た 1 本でも aorta から腎動脈分岐後直ちに 2 本に分岐 しているような場合にはあらかじめ ex vivo での血行 再建を念頭に置き腎移植に臨んでいる．過去に比較的 太い腎動脈分枝でも結禁されていたが（1.5〜3.5 $\mathrm{mm})$ ，最近は径が $1 \mathrm{~mm}$ 以下で腎上極を支配している 動脈以外には血行再建術の適応と考えている．特に腎
下極の分枝は尿管の栄養とも関連するため血管の温存 が図られるべきと考えられる。

Conjoined 法は近接した口径のほほ等しい動脈の吻 合に用いられた。吻合により口径は拡張し，また体内 での吻合も 1 回のみで手技も単純である. End-to-side 法は細い polar artery がある場合に用いやすい. 我久 は 3 本以上の分枝がある場合や， 2 本でも摘出後の動 脈の長さの不足あるいは口径差が生じた場合には前記 の 2 法が困難であることが多いために HGA graft 法 を行った。この方法の利点は，内腸骨動脈は分枝が豊 富なことから, 複雑な血行再建にも対応可能であるこ と，人工物ではない動脈グラフトであり，長期間にわ たって動脈圧に耐えうること，摘出しやすいことなど があげられる。

以上の 3 方法とも体外手術で行った。 Graft は十分 灌流されれば，単純冷却下では総阻血時間を延長する ことが可能である．また，良好な視野を確保できるの で，より慎重な観察と複雑で細い血管吻合を確実に施 行できる ${ }^{1)}$.したがって, 我々は血行再建は体外手術で 行うことを原則としている.

一方，体内で血行再建を行なう方法は視野及び操作 性の悪さ, 温阻血時間の延長, back bleeding などの欠 点があるため1), 我々はこのような術式は近年行って いない.

体外手術に伴う最大の問題点は, 総阻血時間の延長 であることはいうまでもない.しかし，今回のわれわ れの検討からは総阻血時間の延長にも関わらず術後早 期の腎機能は全例とも良好な值を示しており（GFR 43 $77 \mathrm{ml} / \mathrm{min}$.), 手術の合併症も特に問題になるもの はなかった.Accessory artery を結禁した 2 症例では 腎実質欠損像が75\%に認められたことから総阻血時間 が延長してもネフロンの温存を考慮すべきと考えられ る.

血行再建を行った 11 例中 2 例において腎動脈分枝が 閉塞し腎梗塞が発生した。この原因として手技的な関 与も考えられるが, ciclosporin による凝固能六進が知

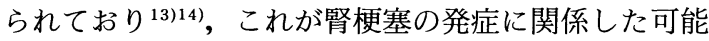
性も考えられる. 我々は術後の抗凝固療法は一般的に 行っていなかったが，今後使用を考慮すべきと考えら れた。

腎移植後は術式の如何に関わらず，ネフロンを減少 させる様々な要因が発症しうる，すなわち，急性拒絶 反応, ciclosporin の腎毒性, 動脈硬化性病変, 原疾患 の再発などによるネフロン量の低下である. 
Hyperfiltration 仮説によると, ネフロン量の減少によ り個々のネフロンにより大きな負荷がかかるようにな り，そのため overworked なネフロンの肥大そしてそ れに続く硬化が起こり, 更なるネフロン量の減少とい う悪循環に陥り，腎機能の悪化をもたらすとされてい る ${ }^{11121}$.このような hyperfiltration を少しでも予防す るためにも, 体外手術による腎動脈の再建を積極的に 施行してネフロンの温存につとめるべきであると我々 は考えている．今回の検討ではネフロン温存による hyperfiltration の予防効果は明らかではなかったが, グラフトの予後に血行再建術が貢献するか否かは長期 の follow up が必要である.

\section{結語}

1. 血行再建術を施行した症例では結禁を行った症 例より総阻血時間が長かったが，全例移植直後より利 尿が得られ急性尿細管壊死は見られず, 良好な腎機能 が得られた。

2. 腎動脈分枝を結禁した場合及び imperative surgery が行われた場合は GFR に対する影響は見られな かったものの, 腎梗塞を起こす傾向にあった.

3. Accessory artery を結禁した 4 例中 3 例 (75\%) に腎動態シンチ上明らかな腎実質欠損像を認めたが, 血行再建術を行った 11 例全例で術後 6 日以内は欠損像 を認めずネフロンの温存が可能であった。

4. Elective surgery の際の血行再建成績を考慮し, 術前の注意深いdonor 腎動脈の評価は重要である.

\section{文献}

1) Novick, A.C., Magnusson, M. and Braun, W.E. : Multiple-artery renal transplantation: Emphasis on extracorporeal methods of donor arterial reconstruction. J. Urol., 122, 731-735, 1979.

2) Murray, S.P., Kent, C., Salvatierra, O. and Stoney, R.J.: Complex branch renovascular disease: Management options and late results. J. Vasc. Surg., 20, 338-346, 1994.

3) Levinson, S. and Ehrenfeld, W.: Replacement of renal artery aneurysm with branched hypogastric artery autograft. J. Vasc. Surg., 124, 685-686, 1972.

4) Novick, A.C., Jackson, C. and Straffon, R.: The role of renal autotransplantation in complex renovascular reconstruction. J. Urol., 143,
452-347, 1990.

5) Harris, J., Walker, P., White, G. and May, J. : Bench repair of complex renal arterial lesions. Ann. Vasc. Surg., 6, 225-231, 1992.

6) Haddad, M., Barral, X., Boissier, C., Bouilloc, $\mathrm{X}$. and Beraud, A.: Extracorporeal repair of renal artery branch lesions. Eur. J. Vasc. Surg., 3, 435-441, 1989.

7) Belzer, F.O., Schweizer, R.T. and Kountz, S.L. : Management of multiple vessels in renal transplantation. Transplant. Proc., 4, 639-644, 1972.

8) Dean, R., Meacham, P. and Weaver, F.: Ex vivo renal artery reconstructions: Indications and techniques. J. Vasc. Surg., 4, 546-552, 1986.

9）安村忠樹, 大森吉弘, 相川一郎, 福田雅武, 中井一 郎, 松井 英, 井岡二郎, 野村秀人, 門谷洋一, 山 本博史, 松村武男, 木村敏之, 岡 隆宏: 複数腎動 脈を持つ移植腎の手術手技と問題点. 移植, 21,36 $-41,1986$.

10）丹田勝敏, 竹内一郎, 金川匡一, 関 利盛, 野々村 克也, 小柳知彦, 富樫正樹, 力石辰也：Donor 腎血 管異常に対する血管再建の経験。腎移植・血管外 科, 6, 70-75, 1994.

11) Terasaki, P.I., Koyama, H., Cecka, J.M. and Gjertson, D.W.: The hyperfiltration hypothesis in human renal transplantation. Transplantation, 57, 1450-1454, 1994.

12) Brenner, B.M., Meyer, T.W. and Hostetter, T. H.: Dietary protein intake and the progressive nature of kidney disease: The role of hemodynamically mediated glomerular injury in the pathogenesis of progressive glomerular sclerosis in aging, renal ablation, and intrinsic renal disease. N. Engl. J. Med., 307, 652-659, 1982.

13) Grace, A.A., Barradas, M.A., Mikhailidis, D.P., Jeremy, J.Y., Moorhead, J.F., Sweny, P. and Dandona, P.: Cyclosporin A enhances platelet aggregation. Kidney Int., 32, 889-895, 1987.

14) Sawaya, B., Provenzano, R., Kupin, W.L. and Venkat, K.K.: Cyclosporin-Induced Renal Macroangiopathy. Am. J. Kidney Dis., 12, 534 $-537,1988$.

15）富樫正樹, 柿崎秀宏, 坪 俊輔, 関 利盛, 小柳知 彦，中西正一郎：腎動脈瘤を有したドナー腎の移 植. 臨泌，43，141-144，1989. (1996年1月24日受付，11月18受理） 